\title{
Section News/Nouvelles des sections
}

\section{Vancouver}

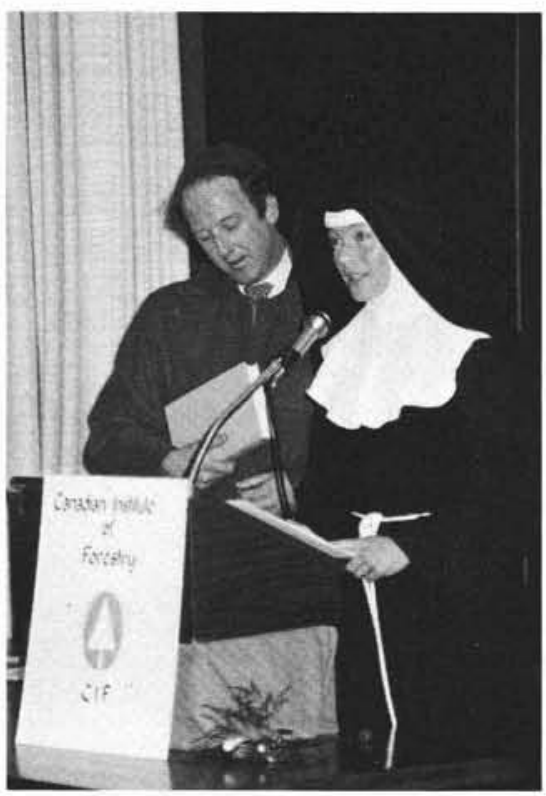

Melissa Hadley and Richard Campbell reciting poetry in Vancouver

Under the guidance of Vice-Chairman Rod Beaumont, the Vancouver Section celebrated 75 years of CIF on February 8 at its annual "Spouses Night", billed as "Pipes, Poetry and Pioneers". Dick Herring led the assembled throng to dinner with a capable rendition from his bag pipe repertoire. Mark Gormely, a long time member. recounted the history of the Vancouver Section, with vivid anecdotes about lively meetings and personalities in the past Your faithful correspondent, assisted by the gentle charm and wit of Melissa Hadley, presented a poem to commemorate the occasion:

On the 75th Anniversary of the CIF/IFC Lief and Eric, who saw our eastern shores Just like the later European explorers,

Discovered that the land was rife with trees The settlers soon thrived, by cutting these. The mills were built, an industry was born The Canadian Society of Forest Engineers was formed,

This is a tale from its historic page

About a seventy-five year pilgrimage.

The journey was begun in nineteen hundred eight

In Montreal, by twelve who charteed out our fate.

Led by B.E. Fernow, as first president

They were a lofty lot, if not heaven sent;
They were, it's said, both keen and full of drive

To see a new profession grow and thrive.

Mighty oaks from tiny acorns grow

The roots grew down, the branches spread, and so

By 1930, a Western Section had been cloned

And since then twenty-two more section seeds were sown

The Chronicle was spawned, its esoteric pages

To be unread by every-one, for ages

And as we grew to be three thousand strong

The dues, at first five bucks, weren't that for long.

The name was changed in 1950, to L'Institute Forestier du Canada, si vous Parlez l'anglais c'est Canadian Institute of Forestry

In both official languages, a tree's a tree.

In early days protection was the quest

And then sustained yield became the test, Now we are developing the means

For tree improvement and for better genes, And integrated use of forest resources

So loggers can exist with fish and horses.

In 1983 we celebrate

A seventy-five year pilgrimage, a great

Time to rejoice and cheer in lowly rhyme

That we in Canada have trees to climb.

The pilgrimage will still go on and on

The trees, we hope, they never will be gone.

And seventy-five years hence there's sure to be

Two clowns dressed up and reading poetry.

Earlier meetings this year included a panel discussion on the fisheries-forestry interface in November, with Peter Pearse who had just completed a Commission of Inquiry in West Coast Fisheries Policy, as moderator. Speakers were Forbes Boyd of the federal Department of Fisheries and Oceans, Jim Walker of the provincial Fish and Wildlife Branch, and Bruce Devitt of Pacific Forest Products Ltd.

In December, the program focused on Second Growth Management, with Bill Backman acting as moderator and Peter Ackhurst of the Ministry of Forests, consultant George Nagel and Dr. Chad Day of Simon Fraser University as speakers. Forest Research was the topic for January's meeting. Moderating duties were undertaken by Brent Sauder, and speakers were Otto Forgacs, Senior VicePresident, Research and Development, MacMillan Bloedel Limited, Jim Danger- field, Director of Research, Ministry of Forests, and Greg Walden, Director of the Western Laboratory of Forintek.

\section{Rocky Mountain Section}

\section{National Forest Week}

The desgination of Smoky Lake and district, Alberta as the Forest Capital of Canada for 1983 was announced on April 29 1983 by Ken Armson, President of the Canadian Forestry Association. CFA Directors met in Edmonton during National Forest Week for their annual meeting.

The recognition of Smoky Lake and district ties in with the declaration of May 1 through May 7 as National Forest Week across Canada.

Smoky Lake's recognition as the Forest Capital of Canada for 1983 was marked by the presentation of a certificate signed by the Governor-General Edward Schreyer patron of the Canadian Forestry Association.

The certificate reads in part:

"This special recognition has been extended to the people and officials of Smoky Lake and district for their enthusiastic co-operation, interest and support of the Alberta Forest Service Pine Ridge Forest Nursery which will grow and ship 36 million white spruce and lodgepole pine seedlings this year in the interests of forest renewal in Alberta."

Special events were held in Smoky Lake on May 2 including an official opening and presentation of the certificate, a reception and luncheon, ethnic dancers, Alberta Forest Service fire fighting demonstrations, logger sports show, tours of the Pine Ridge Forest Nursery, and the premier showing of a 24-minute full color motion picture entitled "Forests for the Future".

Many other communities in Alberta also celebrated National Forest Week by holding various activities such as parades public displays, and three planting ceremonies.

National Forest Week in Alberta was coordinated by an AFA Steering Committee headed by Dave Kiil of the Canadian Forestry Service. Other organizations participating included: the Alberta Forest Service, Canadian Institute of Forestry. University of Alberta, Northern Alberta Institute of Technology. Alberta Forest Products Association and the International Woodworkers of America.

The CIF/RMS was represented by Howard Pratley on the National Forest 
Week Coordinating Committee. The RMS representative was requested to coordinate the public relations component which included the development and distribution of information and media kits, and copy material for the media. Thanks are extended to Jim Pearse of the Alberta Forest Service and Harold Sellars of the Public Affairs Bureau for their valuable assistance advice.

\section{Alberta Forester Honoured}

Gregory P. Stevens, long-time conservation officer with the Alberta Forestry Association, has been twice honoured this year.

On February 22nd Stevens was awarded the Governor-General's Conservation Award during the annual dinner of the Travel Industry Association of Canada (TIAC) in Vancouver. The TIAC honour was presented on behalf of His Excellency Governor General Edward Schreyer by the Lieutenant-Governor of British Columbia.

On May 2nd, the Outdoor Education Award was presented to Greg during official ceremonies designating Smoky Lake as Forest Capital of Canada. This honor was presented by Ken Armson, President of the Canadian Forestry Association, and Al Brennan, outgoing President of the Alberta Forestry Association in join recognition by these two associations for the outstanding contribution to youth education in natural resources by $\mathrm{Mr}$. Stevens over many years.

Greg Stevens has devoted more than 20 years to making the young people in Western Canada more aware of their forest and resource heritage. With his wife Gladys he has visited the schools throughout the region where he has been warmly welcomed for his inspirational and informative stories and lessons about the forests and the need to look after them. He has travelled through all kinds of weather, following a schedule that few could keep up to. $\mathrm{He}$ is now 78 years of age, and about to retire (for the second time).

The teachers as well as students have looked forward to Greg's visits and messages. During the last ten years, the Alberta Forestry Association estimates that 660000 students and 20000 adults have learned about forest conservation from this remarkable person. For the 20 year period during which he toured western schools, his audience would have exceeded one million.

The two awards which honoured Greg Stevens this year are tribute and recognition of an outstanding contribution to public awareness. Although about to retire, Stevens is still youthful in appearance and filled with enthusiasm when introducing young people to the story of resources.

The Alberta Forestry Association, a member of the Canadian Forestry Association federation, is dedicated to improving awareness, understanding and support for better forest management from the public of all ages.

\section{Public Hearings on Future of Agricultural Land Base}

Public hearings on the future of Alberta's agricultural land base will be held this fall by the Environment Council of Alberta (ECA).

A five-member panel recently appointed by cabinet will visit 16 Alberta centres after mid-October to hear views on the agricultural land base.

The Rocky Mountain Section plans to make submissions at many of the hearing locations.

\section{RMS Annual Meeting}

The RMS Annual Meeting was held on March 25 and 26, 1983 in Edmonton. The theme of the meeting was "Forest Land Use - Are We Meeting the Challenge?"

The technical session program proved to be very interesting with excellent speakers and presentations. The program included: Mr. Chris Andersen, Woodlands Manager, Canadfian Forest Products Ltd. - Alberta Division, who spoke on the Forest Industry Challenge - "How much can we compromise". Dr. James Butler, Associate Professor, Department of Forest Science, University of Alberta, addressed the topic of Alberta's Wildland Resource - "The Challenge of Changing Public Demand". Dr. Butler was followed by $\mathrm{Mr}$. Fred McDougall, Deputy Minister, Alberta Energy and Natural Resources who spoke on "The Integrated Land Use Challenge". Mr. Alistair Crerar, Chief Executive Officer, Environment Council of Alberta presented the ECA Challenge - "Closing the Gap". The final presentation was made by $\mathrm{Mr}$. Bob Udell, Assistant Chief Forester, St Regis (Alberta) Ltd. and Chairman of the RMS. Bob addressed the Rocky Mountain Section Challenge - "Where we have been. Where we are going". Howard Prately chaired this program and the moderator was Brian MacDonald.

The banquet which followed provided a good opportunity to socialize and discuss the afternoon session. The banquet guest speaker was the Dr. Ian C. Reid, MLA Edson Constituency

\section{RMS Business Meeting}

A highlight of the March 26, 1983 RMS Business Meeting was a discussion regarding the establishment of the profession of forestry in Alberta. There were 58 people in attendance at this meeting. Peter Murphy. Chairman of the ad hoc Committee investigating the possibility of establishing a Professional Foresters Association was invited to review the proposed amalgamation with Professional Agrologists. Peter conducted an excellent review of the features of the proposed amalgamation. The discussion closed with a carried motion which stated that the CIF/RMS sanction to date the efforts of the ad hoc Committee (RMS has one designated representative on this Committee) pursuing the Professional Foresters status and further sanctioned the Committee to represent the CIF/RMS in the continuing pursuit of amalgamation with the Professional Agrologists.

\section{RMS 1983-84 Council}

\section{Director}

Bob Udell - St. Regis (Alberta) Ltd.

Chairman

Lorne Brace - Canadian Forestry Service

Vice-Chairman

Howard Pratley - University of Alberta - Forestry

Secretary-Treasurer

Ross Waldron - Canadian Forestry Service

Councillors

Brian MacDonald - Procter \& Gamble Cellulose Ltd.

Con Dermott - Alberta Forest Service

Dick Dempster - W.R. Dempster and Associates

Ross Risvold - Forest Technology School

Brian Adams - Canadian Forest Products Ltd

Dean Marshall - Spray Lakes Sawmills Ltd.

John Powell - Canadian Forestry Service

Howard G. Pratley

\section{Caribou}

1983 is the 30th Anniversary of the Caribou Section.

Although out of the Chronicle news for some time, the Section has been busy Presently it has 104 active members and ten student members. Twenty-four members were lost to the new Smithers Section, which formally became active in September 1982. Work is proceeding on the formation of a Williams Lake Section. It appears as though the Caribou Section will lose another one-third of its members there.

The Section Regional Public Affairs Committee, under the guidance of Flemming Einfeldt submitted reviews of Kakwa and $\mathrm{Mt}$. Robson Deferred Planning Areas to Lands Branch, of the Ministry of Lands, Parks and Housing. (Deferred Planning Areas are areas which are not committed to any specific use. They are set aside until further analysis and discussion enables a more positive decision on land use). Dale McLean is now assuming the leadership role with this committee.

The National meeting, hosted by this section was a success. 160 fully paid registrants and forty spouses attended. with up to 200 people present at some events.

The past year has seen a number of interesting speakers present views to this Section. 
Whitey Anderson of Jacobson's Forest Products and Steve Willett of Fish and Wildlife Branch discussed progressive harvesting.

A seminar on the use of herbicides in forestry was presented by Frank Dost of the Department of Agriculture Chemistry, Oregon State University, Jack Toovey, Chief Forester BCFP, Bob Nixon Executive Director, Legislative Office, Greenpeace, Charlie Johnson, Director of Silviculture Branch, BC Ministry of Forests, and Bob Deboo, Manager of Pest Management Branch, BC Ministry of Forests.

Bill Young, Chief Forester of the Province of $\mathrm{BC}$ spoke to the section on some happenings in forestry in British Columbia.

Dr. Roy Strang, Executive Director Forest Research Council of BC discussed forestry research.

John Cox, Director, Information Branch, BC Forest Service, and Mike Halleran, Director, Communications Branch, Canada Fisheries and Oceans, presented views on public involvement and its implications on forest management in BC

A demonstration forest, east of Prince George, BC has been set up by a committee headed by Bill Williams of this Section. It was officially opened on September 24 th, 1982. The theme of this project "Forest Ecology" is highlighted by an interpretive trail $1.9 \mathrm{~km}$. Iong. To date the trail has been well used by the public.

John Long

\section{Saskatchewan}

The Saskatchewan Section held its annual meeting on April 7 th, 1983. The afternoon technical session theme was forestry education in Saskatchewan. Several guest speakers were called upon to cover the subject matter. George Urban, a Vice-Principal in the Prince Albert school district, talked about his involvement in curriculum development for the CPPA project, People of the Forest. Prince Albert is one of the pilot communities where the program is being developed and Mr. Urban provided details as to the progress to date.

Steve Smith, President of the Saskatchewan Forestry Association talked about the development of Project Learning Tree in Saskatchewan. The project is endorsed by the Saskatchewan Department of Education and the Saskatchewan Forestry Association is currently awaiting a contract from the American Forest foundtion. The Saskatchewan Forestry Association is planning to organize a week-long teacher's tour of forestry related activities in conjunction with Project Learning Tree seminars. The Saskatchewan Section has pledged full support of the Saskatchewan Forestry Association project.
Lorne Sparling. Director of Institutes \& Community Colleges, talked to the section about the Renewable Resources program at Kelsey Institute in Saskatoon and about forestry courses to be offered at a new technical institute currently under construction in Prince Albert.

The final speaker for the afternoon was Dr. Paul Woodard of the University of Alberta, Department of Forest Science. Dr. Woodard's talk was titled "Forestry at the University of Alberta - our goals and graduates", which provided an insight into current university level education in forestry

The evening session was a casual affair with some of the more senior section members recounting their early "adventures" in forestry in Saskatchewan.

The election of new officers took place at the evening meeting with the following results:

Section Rep. to Bd. of Dir. Steve Price

Chairman

Bob Stoddard

Vice-Chairman

Chris Lee

Secretary Treasurer

Gord Frey

Councillors

Tom Ward

Madan Pandila

Steve Meriam

Walter Koch

John Thompson

Chris Lee

\section{Southern Ontario}

The SOS's annual dinner meeting was held on March 29th, 1983, at Sir Sanford Fleming College in Lindsay. About 60 people attended, including Mr. J. Cayford, the national CIF president. Mr. H. Faulkner director of the SOS, called upon Mr. Cayford to present the SOS Student Achievement Award for Sir Sanford Fleming College to Nancy M. White, Dr. N. Foster, of the Great Lakes Forest Research Centre in Sault Ste. Marie, presented an informative review of his work on the effects of acid precipitation on two forest ecosystems. Thanks to everyone who attended and made this meeting such a success and congratulations Nancy!

The 75th Anniversary Annual Meeting of the SOS which was planned for the week end of May 14 - 15th, 1983, had been postponed until October 22nd - 23rd 1983, to provide the time for better planning. Information and registration materia will be sent out in early July so plan now to attend.

Nominations can still be made for 'Section Member of the Year'. Submissions should be sent to J. McNeil, Secretary/ Treasurer. For terms of reference, contact R. Kelertas, Chairman.
The CIF's Ring Ceremony for the Faculty of Forestry, University of Toronto, was held on March 11th at the Four Seasons Sheraton Hotel in Toronto. The graduates were presented with their rings by $\mathrm{Mr}$. $\mathrm{J}$. Cayford. This highly popular event was well attended by staff, students, professional foresters and parents. In addition, R Bourchier - Executive Director of the CIF. P. Hare - President of the Forestry Alumni Association, K.G. Greaves - President of the Ontario Forest Industries' Association, a representative of the Ontario Forestry Association and R. Kelertas - Chairman of the SOS, were present. Best of luck to all the graduating class.

Volunteers are still needed to help with our public service summer project (a free consultation and information service to non-profit organizations). If interested please contact J. McNeil.

Diana Morgan John McNeil

\section{Ottawa Valley}

On February 8th the section council had the opportunity of having supper with the National Executive. This was an enjoyable and informative evening spent together and provided an opportunity to hear of some of the activities planned by our executive for the coming year.

Gilbert Paillé, First Vice-President, mentioned that $\$ 20000$ were still required for the forest management book being written by Don Mackay. Three publishers are being approached for the book, which will be translated at no cost to CIF members.

The International Forestry Congress to be held in Quebec City in 1984 will be the largest meeting the CIF has ever been involved with; 2500 delegates are expected. Four forestry organizations will be meeting together in Quebec City: the

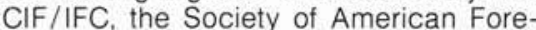
sters (SAF), the Ordre des Ingéniers Forestiers du Québec (OIFQ), and the International Union of Societies of Foresters (IUSF). Gilbert hopes that the Institute, including the working groups, will be active in planning the scientific aspects of the Congress. He also noted that many working groups "should be working more" and he is now carrying out a review of the WG structure as well as the management structure of the CIF organization.

Jim Clark, 2nd Vice-President, spoke about finances and membership, the latter which now stands at 2385. The financial picture shows a slight surplus for the present fiscal year.

Past President George Garner spoke of the need to improve on information exchange among all levels of the Institute, and to do so by implementing the three C's, namely: Coordinate/Communicate/Cooperate.

Executive Director Bob Bourchier said he finds his work interesting, and he foresees the CIF continuing and increasing its activities in preparing significant position 
statements about forestry problems in Canada.

Jim Cayford, President, expressed his appreciation to all those who helped bring the Ottawa office to the fully operational stage it is now in. He stated that the Institute's move to Ottawa is already showing results in the CIF's ability to develop contacts at the federal political level.

Earlier in the day the Executive had breakfast with the Deputy Minister of Environment Canada, Mr. Jacques Gérin, and had lunch with the Minister, John Roberts. Mr. Roberts had appeared well briefed and demonstrated a good understanding of forestry issues. The minister voiced concern that there are 70 organizations speaking out on forestry in Canada and that this communication effort could be streamlined if the CIF took a coordinator's role.

It was noted that 1983 is the 75 th anniversary of the CIF and every section is encouraged to suitably mark the occasion, possibly with a brief historical review submitted to local newspapers for publishing.

On Tuesday, March 29th, the Ottawa Valley Section organized a seminar on the Gypsy Moth. The meeting was held at the Kemptville College of Agricultural Technology in Kemptville, Ontario. Three qualified guest speakers made presentations:

Dr. G. Howse, Great Lakes Forest Research Centre, CFS, Sault Ste. Marie, Ontario

Mr. B. McGauley, Ontario Ministry of Natural Resources, Maple, Ontario

Mr. A. Schmidt, Agriculture Canada, Ottawa

A film was shown which outlined the life cycle of the pest and made clear how destructive this insect has been. Since the gypsy moth has been present in Ontario for several years, and that recent insect survey data indicate a further increase in its numbers, potential control options were discussed.

In view of the serious nature of this forestry problem it was especially disappointing that only a handful of people attended the seminar.

Greg Crook

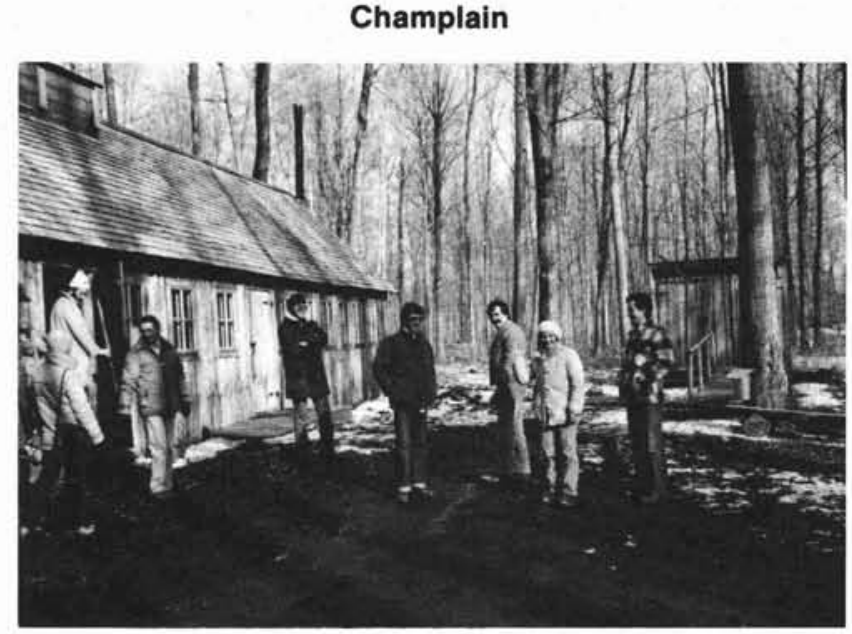

Enfin, le printemps est arrivé! Et au Québec, cet évènement est habituellement marqué par la journée à la Cabane à sucre. C'est ainsi que samedi le 26 mars 1983 , sous un soleil radieux, les membres de la Section et leurs amis(es) se sont rendus nombreux au Bois de BelleRivière. Celui-ci est la propriété de la Société Immobilière du Canada (Mirabel) Ltée. Il a été conçu pour ceux qui aiment la nature et qui désirent mieux la connaître tout en s'y récréant.

Sur les lieux, nous avons été accueillis par notre hôte, madame Francine Lalande. ing. f. Après avoir assisté à une présentation audio-visuelle sur le temps des sucres, nous nous sommes rendus à la cabane à sucre de monsieur Nepveu. Celui-ci nous a fait une présentation sommaire de ses équipements (système de tubulures; pompe à vide, etc. ...), avant que l'on nous serve un repas traditionnel du temps des sucres ("oreilles de crisse", etc. ..). Comme dessert, on a eu droit aux oeufs dans le sirop (un délice!) et à la tire d'érable sur la neige.

Après le repas, madame Lalande nous invita à une visite à pied des différents aménagements du Bois, laquelle fut plus que bienvenue après cette grande bouffe. Au retour, on nous a remis des échantillons des produits de l'érable, une gracieuseté de la Société.

Bref, ce fut une journée magnifique. Une expérience à renouveler!

Yves C. Dubé

\section{The Annual Meeting Schedule}

1983 - October 3-6, Sault Ste. Marie, Ontario Theme: "Forestry in Canada: Yesterday, Today and Tomorrow"

1984 - August 5-9, Quebec City, Quebec Theme: "Forest Resources Management - The Influence of Policy and Law"

This is a joint meeting of l'Ordre des Ingénieurs forestiers du Québec, the Society of American Foresters and the International Union of Societies of Foresters, of which the Canadian Institute of Forestry is a member.

1985 - September 22-26, Winnipeg, Manitoba Theme: The Forest - Who Manages?

1986 - Victoria, BC 